\title{
ДЕДОЛЛАРИЗАЦИЯ МИРОВОЙ ЭКОНОМИКИ КАК ФАКТОР ПРОТИВОДЕЙСТВИЯ АГРЕССИВНОЙ ПОЛИТИКЕ США
}

\author{
(c) 2018 Ливенский Валентин Михайлович \\ доцент кафедры финансов \\ Полесский государственный университет \\ 225710, Республика Беларусь, г. Пинск, ул. Днепровской флотилии, 23 \\ E-mail: livey@tut.by
}

В статье анализируется внешняя политика США, стремясь сдерживать развитие стран, которые они считают своими конкурентами на мировых рынках; обосновывается тот факт, что ряд ведущих стран в ближайшем будущем, предвидя негативные последствия для мировой экономики, будут проводить политику дедолларизации своих экономик.

Ключевые слова: мировая экономика, торговые войны, санкции, кризис, дедолларизация экономик.

Сегодня ряд ведущих экспертов, в том числе и в самих США, уже проводят параллели между текущей ситуацией и периодом до Второй мировой войны. Тем более, что в американской истории уже были примеры торговых войн с применением санкций, импортных пошлин, пересмотра существующих соглашений и договоров [1].

И хотя, как известно, исторические процессы никогда не повторяются с абсолютной точностью, тем не менее, многие действия администрации Трампа и его идеологическая риторика говорят в пользу того, что во внешней политике США вновь возвращаются к смеси изоляционизма и империализма, стремясь «сдерживать» развитие стран, которые они считают конкурентами на мировых рынках и «угрозой для национальных интересов» [2].

Есть ещё один фактор, который заметно поменялся по сравнению с тем, что было лет 10 назад. Это Китай и его отношения со своими партнёрами, которые приобрели в глобальном пространстве заметно большее значение. Сегодня это вторая по величине экономика в мире с постоянно растущими запросами, которая выстраивает свои партнёрские отношения без оглядки на США. Поэтому соперничество с Китаем будет одним из наиболее важных факторов для мира в последующие 10 лет. Применим здесь концепцию под названием «ловушка Фукидида», которая свидетельствует, что растущая держава всегда ведёт соперничество с существующей державой и вероятность войны повышается. Данный постулат сработал 16 раз за последние 500 лет - во всех подобных случаях происходили войны [3].
Это не значит, что войны сейчас будет не избежать. Но это означает, что соперничество между странами и их близкими партнёрами, которое начинается в экономической сфере, может стать политическим и военным. Тем более, что экономика Китая, если не остановить её текущее бурное развитие, будет существенно больше экономики США уже через 20 лет. Поэтому здесь пока присутствует «мягкое соперничество». Мы пока находимся на раннем этапе этих процессов, которые в скором времени определят, как это соперничество будет развиваться в ближайшем будущем [4].

Но что мы уже наблюдаем сейчас? Напряжённость усиливается по всем направления, по мере того как Китай, Россия, Иран, Турция и другие страны устанавливают многополярный мировой порядок. США отвечают этому вызову - на фоне агрессивного настроя американского истеблишмента стала усиливается военная и экономическая напряжённость. И уже довольно сложно остановить смещение мирового порядка в сторону однополярной системы управления и это заставляет государство США использовать любой вид оружия для достижения своих целей, при этом неважно, каковы будут последствия подобной безрассудной внешней политики США для всего остального мира.

Приведём ряд конкретных примеров. В то время, когда провинция Идлиб в шаге от освобождения от террористов Сирийской Арабской армией (SAA), усиливается напряжённость между США и Сирией (и союзниками Сирии). Кажется, что каждую значительную военную кампанию SAA сопровождают ложные сообщения западных СМИ и правительств, предупреждающих о 
неминуемом использовании химического оружия SAA. Напряжённость растёт и потому, что президент выразил желание нанести удар по Сирии из-за предполагаемого использования химического оружия, и это даже без проведения какой-либо независимой проверки. Угрозы США, Великобритании и Франции, заявляющих о бомбардировке российских войск в Сирии, ежедневно и с искажением озвучиваются в западных СМИ. Это безумие достигло уже совершенно невероятных уровней.

События в Сирии, похоже, сопровождаются настойчивыми попытками Украины и США саботировать минские соглашения, разжечь заново конфликт, чтобы обвинить в этом Россию.

Ещё более фальшивые обвинения против Москвы в отравлении бывшего российского шпиона Сергея Скрипаля в Великобритании вышли после обвинений Москвы о вмешательстве в президентские выборы в США.

К накаляющейся ситуации можно добавить и постоянные угрозы, наряду с экономической и финансовой войной, посылаемые в адрес Ирана Израилем, Саудовской Аравией и США, претензии разного рода США к Турции [5].

Неудивительно, что в таком контексте Российская Федерация только что провела самые крупные военные учения за всю свою новую историю. Не следует удивляться тому, что и Китай направил тысячи солдат для участия в этих учениях, заставив обратить на это внимание Вашингтон и Запад.

Осенний Восточный экономический форум во Владивостоке является ещё одним важным моментом в новой китайско-российской стратегии, цель которой состоит в том, чтобы ограничить и, по возможности, изолировать хаос, вызванный США, поддержать страны, которых коснулось влияние Вашингтона, и расширить сотрудничество во всех возможных направлениях.

Экономические связи между производственными китайско-российскими системами двух стран заслуживают сейчас особого внимания и это партнёрство выходит далеко за пределы России и Китая. Технологическое сотрудничество расширяется в таких регионах, как Африка и Юго-Восточная Азия, предлагая важные соглашения с третьими странами. Специализацией Москвы является продажа ядерной энергии и оружия, в то время как щедрые кредиты и совместная разработка основных ресурсов - приоритет Пекина. Такие предложения помощи важны не только для стран третьего мира (Китайско-российские действия в Африке постепенно разрушают структуру западного неоколониализма), стремящихся освободиться от колонизации Запада, но также и для тех стран, которым необходим новый многополярный мировой порядок. Действительно, стратегический квадрат между Тегераном, Турцией, Пекином и Москвой вовлекает все соседние страны в большой геополитический вальс. А создание альтернативной системы SWIFT сможет снизить централизованную роль американских банковских учреждений и политический вес доллара США.

Как видим, в целом многополярный порядок международных отношений уже развивается на обширных территориях планеты как с военной, так и с экономической точек зрения. Дедолларизация при этом - это неизбежный этап для достижения значительного экономического суверенитета [6]. Как видим, Китай, всё более поддерживаемый Россией, предпринимает решительные шаги для создания жизнеспособной альтернативы тирании доллара США в мировой торговле и финансах. Уолл-стрит и Вашингтон не удивлены этому, но остановить это они не в силах, пишет американский экономист Фредерик Уильям Энгдаль [7].

На этом фоне логика недавнего введения тарифов на китайскую продукцию на сумму более \$200 млрд. больше похоже на шаг отчаяния. Даже исторические союзники США - Южная Корея, Пакистан, Индия и Турция - не раз подчёркивали, что опасаются иррациональности Вашингтона и политики «Америка прежде всего» и ищут пути, чтобы включиться в обширный евразийский континент и участвовать в экономических и финансовых форумах для диверсификации финансирования и сотрудничества на промышленном уровне.

Завершает эту картину внутренняя экономическая борьба: европейские союзники вынуждены страдать от огромных экономических потерь в результате санкций против России, Китая и Ирана. Торговые тарифы, особенно в таких странах, как Турция, Япония и Южная Корея, заставляют союзников США изучать альтернативы с точки зрения доверия и сотрудничества.

Европейский истеблишмент в некоторых западных странах, таких как Германия, Франция и Великобритания, похоже, решил пока переждать. Но многие интуитивно поняли, что на самом деле происходит в западном мире. Известные 
лидеры начинают предпринимать серьёзные шаги для изучения возможных альтернатив союзу с США.

Вашингтон встречает все эти сценарии со скептицизмом, досадой и отвращением, опасаясь потерять важные страны и способность устанавливать региональное равновесие на планете. И многих аналитиков удивляет сегодня упрямство и глупость американских политиков. Чем больше они пытаются сохранить однополярный порядок в США, тем больше стимулов они дают другим странам развивать многополюсную систему. Но США по-прежнему сохраняют дипломатическое высокомерие и стратегическую глупость.

И каждый сценарий, связанный с США, теперь необходимо рассматривать с учётом двух факторов: попытки сохранить империалистическую позицию и внутренней борьбы с элитами. А нынешняя макроэкономическая среда всё больше напоминает ситуацию 1930-х гг. Кроме того, прошлый опыт особенно актуален сегодня, так как это был один из периодов, когда ряд крупных экономик столкнулись с проблемой 3Д (долга, демографии и дефляции). Действительно, непродуктивное накопление долга стало причиной как Великой депрессии 1930-х гг., так и Великой рецессии 2008-2009 гг. Кроме того, более слабые демографические тенденции в ряде стран в течение обоих периодов времени также оказывали негативное влияние на потенциальный рост. Падение частного спроса в связи с последующим процессом сокращения доли заёмных средств создало интенсивное дефляционное давление.

Таким образом, как утверждают аналитики банка Morgan Stanley, ситуация конца 30-х гг. сейчас может повториться. Однако здесь стоит учитывать, что после повторения кризиса 30-х гг. экономика США восстанавливалась очень медленно, к более быстрым темпам роста она перешла только после начала Второй мировой войны. Дело в том, что военные расходы являются одним из основных источников роста экономики США. Этот факт ещё совсем недавно повторил бывший глава ФРС Бен Бернанке на панельной сессии «тhe defense economy and American prosperity» («Военная экономика и процветание Америки»), организованной Брукингским институтом (Brookings Institution) в конце 2015 г. И если ситуация всё же будет повторяться, то не исключено, что США понадобится очередная масштаб- ная война, которая будет способна вытащить экономику страны из затяжного пике [8].

Но что же США делать с наметившейся дедолларизацией? Ибо если раньше господство доллара сохранялось, не тая в себе смертельной угрозы, то в последнее время ситуация резко изменилась к худшему. До тех пор пока грязные трюки и махинации Уолл-стрит провоцировали кризисы, страны с профицитом торгового баланса, такие как Китай, Япония, а затем и Россия, не имели альтернативы, кроме как постоянно скупать трежерис США. Вашингтон и Уолл-стрит могли печатать бесконечные объёмы долларов, ничем более ценным не поддерживаемые, кроме как истребителями F-16 и танками Abrams. Китай, Россия и другие держатели долларовых облигаций при этом финансировали войны США, скупая долг США. Тогда у них было мало реальных альтернативных вариантов.

Теперь, по иронии судьбы, две страны, которые в свое время продлили жизнь доллару (Россия и Китай после 1998 г.), рассматриваются большинством стран как потенциальные создатели жизнеспособной международной валюты, поддерживаемой золотом, нефтью, которая сможет снизить гегемонистскую роль доллара уже сегодня. Вот почему в течение нескольких последних лет, как Россия, так и Китай, Индия и ряд других стран, скупают огромные объёмы золота, в основном, чтобы пополнить валютные резервы своих ЦБ, которые до этого момента содержались, по большей части, в долларах и евро.

На фоне всего этого, США просто вынуждены проводить националистический курс развития, считают «нелигитимными» многие международные организации в их текущем виде и будут преследовать только свои собственные интересы. Об этом буквально заявил в своем выступлении на 73-й сессии Генеральной ассамблеи Организации Объединенных Наций Дональд Трамп. Помимо Всемирной торговой организации критике со стороны Трампа также подверглись Совет ООН по правам человека и Международный уголовный суд (также известный как Гаагский трибунал). Высказывания об отказе США от «глобализма» в пользу «патриотизма» ранее неоднократно звучали в комментариях и экс-советника президента США Стивена Бэннона [9].

Отметим, что заявление об односторонних действиях США справедливо не только в плане финансово-экономического давления 
в виде санкций в отношении таких стран как Китая, России, Ирана и Турции. В отношении многих других стран американские власти так же установили торговые ограничения в виде повышения импортных пошлин: речь идёт об Индии, Китае, Канаде, России, Турции, странах Европейского союза. А здесь уже американская уверенность в собственной исключительности привела к интересным последствиям: в США думали, что ради возможности сохранить хорошие отношения с «вашингтонским обкомом» элиты самых разных стран, от России и Китая до Евросоюза и Ирана, поднимут бунт против политического руководства своих стран. На практике же получилось нечто иное: США в глобальном мире были всеобщим примером, а стали всеобщей проблемой. И рано или поздно для этой проблемы найдётся адекватное решение.

Таким образом, и что можно уже констатировать, поведение нынешних американских властей стало «односторонним и безответственным». А та экономическая война, которую стремятся развязать сегодня США, нанесёт ущерб всем странам, которые будут в неё вовлечены. Нынешний односторонний и безответственный подход правительства США всё больше и больше втягивает мир в период беспощадной экономической войны. Поэтому, все те страны, которые имеют ориентированную на экспорт модель роста своей экономики, уже сегодня должны совместно объединить свои усилия с другими ответственными государствами для запуска мер по защите всех заинтересованных государств в целях предотвращения в будущем подобных разрушительных торгово-экономических и политических конфликтов. И дедолларизация мировой экономики при этом - это неизбежный этап для достижения значительного экономического суверенитета в будущем.

\section{Библиографический список}

1. Киевич А.В. Программа вновь избранного президента США как олицетворение изменений на макроэкономическом уровне глобальной экономики // Современные аспекты экономики. 2016. № 11 (231). C. 12-24.

2. Аналитический обзор vestifinance.ru. Электронный ресурс. Доступно на: https://www.vestifinance.ru/ articles/107475. - Дата доступа: 27.09.2018 г.

3. Киевич А.В. МИРОВЫЕ ЦБ В ЛОВУШКЕ QЕ. // В книге: Банковская система: устойчивость и перспективы развития. Сборник научных статей восьмой международной научно-практической конференции по вопросам банковской экономики, посвященной году науки в Беларуси. Полесский государственный университет. 2017. С. 72-76.

4. Аналитический обзор vestifinance.ru. Электронный ресурс. Доступно на: https://www.vestifinance.ru/ articles/106875. - Дата доступа: 28.09.2018 г.

5. Там же

6. Там же

7. Аналитический обзор vestifinance.ru. Электронный ресурс. Доступно на: http://www.vestifinance.ru/ articles/91050.- Дата доступа: 18.09.2018 г. 13:12

8. Киевич А.В. Дедолларизация мировой экономики как объективная реальность // Вопросы экономики и права. 2017. № 108. С. 33-37.

9. Там же 